\title{
eMatsheni: The central beer hall as social and municipal infrastructure in twentieth century Pietermaritzburg
}

\author{
Debbie Whelan*
}

\section{Introduction}

The production of buildings does not occur in isolation, particularly those that form part of civic infrastructure. Buildings have impacts on the social, political and physical environments, and in turn once implemented, these inform how environments should or should not be used. The gradual provision of "corporation" facilities in Pietermaritzburg in the twentieth century was no different. The city was compelled to include a number of new structures for which there was no precedent, either architectural or social. Some were technologically based, such as electrical substations which housed the newly installed direct current, and which were objects of protest for many residents while being a necessary component of corporation infrastructure. Others accommodated the different imperatives that contributed towards the gradual swathe of legislation which came to be associated with apartheid. Prior to the Group Areas legislation, large areas of the centre of the city were demographically mixed, meaning that the location of these new buildings to some extent led to the future segregation of the city, and at the same time elicited protests from groups that featured prominently in the struggle against apartheid. The Pietermaritzburg corporation was the key implementing agent in some of these, constructing a central brewery for African beer, a number of beer halls and associated eating houses specifically for black people, as well as hostels for both men and women in the centre of the city.

While authors in the past, such as La Hausse ${ }^{1}$ and Du Plooy ${ }^{2}$ have addressed the African beer halls and the so-called "Durban System" as part of an oppressive municipal system, and in a manner popular in historical writings at the time, this paper intends to question some of these aspects, presenting a different perception of the beer hall as a vital part of social and municipal infrastructure, which sought to address the needs of its users as much as possible. It will focus

Debbie Whelan is an associate professor in the Department of Architecture at the Durban University of Technology. She works generally in the fields of indigenous vernacular structures as well as the history of infrastructure in KwaZulu-Natal. Her specialty is interdisciplinary work between architecture and anthropology. E-mail wheland@dut.ac.za

\section{How to cite this article:}

Whelan D. eMatsheni: The central beer hall as social and municipal infrastructure in twentieth century Pietermaritzburg. Historia. 2015; 1(1), Art. 16 pages.

http://dx.doi.org/10.17159/2309-8392/2015/v60n1a5

1. P. la Hausse, Brewers, Beerhalls and Boycotts: A History of Liquor in South Africa (Ravan Press, Johannesburg, 1988); and P. la Hausse, "The Struggle for the City: Alcohol, the eMatsheni and Popular Culture in Durban 1902-1936", MA thesis, University of Cape Town, 1984; and P. la Hausse. "Beer, Social Control and Segregation: The Durban System and the 1929 Beerhall Riot", BA Honours essay, University of Natal, Durban, 1980.

2. P. Du Plooy, "African Reaction to the Beerhalls", in J. Laband and R. Haswell (eds), Pietermaritzburg 1838-1938: A New Portrait of an African City (Shuter \& Shooter, Pietermaritzburg, 1988), p 142; and P. du Plooy, "Beer and Native Administration: An Introductory Study of the Beer Hall System in Pietermaritzburg, 1908-1937", BA Honours (Historical Studies) University of Natal, Pietermaritzburg, 1987. 
primarily on the considered construction and deployment of the physical building of the Berg Street beer hall, examine it as a product of a carefully constructed process, and further scrutinise its role in post-apartheid South Africa.

The building as "product" is thus a focus in this paper; it will discuss the historically contested position of the city with regard to production of viable spaces for African people, as well as the manner in which the space operated. It will conclude by examining the structure as an artefact of heritage architecture, which can only benefit from creative and responsible adaptive re-use in a post-apartheid South Africa. ${ }^{3}$

\section{The Durban System in Pietermaritzburg}

The beer halls and associated eating houses were a building typology created to accommodate the result of an abstract system of laws: a series of coherent and interconnected structures and functions which implemented the imperative of the colonial legislative framework and at the same time had to organically develop in order to accommodate these constraints. At the core was the Durban System.

This was a structured way in which municipalities in the then Natal supplied uTshwala or sorghum beer to inner city African residents, whilst at the same time controlling the procurement of its ingredients, its manufacture and sale; the manner in which inner city African residents used the city and; most importantly, raised vital revenue for the municipal Native Affairs Departments. The system was seen as a critical step in limiting backyard beer brewing. Funds from this system were ploughed back into the municipal Native Affairs Department budget, with annual allocations from this fund supporting such specific beneficiaries as the native ward at Grey's Hospital, in addition to larger scale projects such as the construction of the Native Village at Sobantu in 1929. ${ }^{4}$ Thus, while the construction of facilities for African people was drawn from a different budget, their design and implementation remained the responsibility of the city, and were awarded the same attention as other products of municipal infrastructure.

The legislation allowing for the beer halls was promulgated with the gazetting of the Natal Native Beer Act in October 1908. Pietermaritzburg lost no time in implementing the legislation; by March 1909, a brewery and 4 beer halls were opened in the city. The central brewery was a vital key in the system, as it was the site for the brewing of beer for distribution to the different beer halls, controlling its quality, and its distribution and access. People tendered for the contract to transport the beer to the beer halls, which were, initially, situated in key

3. It is important to contextualise the main focus of this paper within the political and social climate of the early 1930s. A gradually increasing political will among African residents subsequent to the formalisation of the African National Congress in 1923 and the rise of trade unionism, was supported by the development of a civic society, social clubs, and other organisations arranged along ethnic and class lines. In addition, the economic landscape was scarred for all with the depredations of the post-war 1920s, the local effects of the Great Depression, drought and the Malaria scourge of the early 1930s.

4. Du Plooy, "Beer and Native Administration", p 37. 
areas in which Africans were concentrated, namely the Power Station, Ohrtmann Road (near the quarry), Camp's Drift ${ }^{5}$ and Retief Street. ${ }^{6}$

The first beer halls in the city were almost transient: The rapid implementation of the 1908 legislation was enabled largely by the fact that the facilities were all accommodated in existing buildings, leased from their owners and for the most part in a general state of disrepair. Little money was set aside for their maintenance and operation, until success was proven. For example, the original beer hall in Retief Street was found wanting in an inspection in the early 1920s, which recommended on 27 July 1921 that "a brick floor be laid down at the Retief Street Beer House as it is likely that the Beer House will remain on the present site. The existing mud floor is in a bad state". ${ }^{7}$ For the power station, the Pietermaritzburg Corporation Yearbook of 1918-1919 records that a new brick structure was built at the power station beer hall, replacing the wood and iron structure that had existed there previously. ${ }^{8}$

Thus, these extant buildings provided temporary accommodation for a seemingly marginal activity. ${ }^{9}$ Not even their names were fixed: the central beer hall is named variously in archival material as Church Street, Commercial Road and central beer hall. Such uncommitted titles are also applied to others in the group, such as the later Retief Street / Berg Street beer hall with which this paper will be mainly concerned. To reinforce this air of impermanence, the Natal Directory of 1920 does not mention a beer hall being located in the area around Pietermaritz, Commercial and Church Streets, although there had been one on the site since 1909. The directory preferred an open-ended reference to a "native" eating house at 135 Commercial Road, an Arab store and an enigmatic reference to "natives". It remained figuratively invisible. ${ }^{10}$ Rather than the eating house being the adjunct to the beer hall, the beer hall as the social and economic focus was minimised, and for the general "polite" Edwardian society the eating house had an address and an entry in the Natal Directory. The beer hall remained absent.

Soon after the legislation was promulgated, the corporation entered into a contentious agreement with William Leathern, who owned property on Church Street, and Commercial Roads, ${ }^{11}$ leading to a two year agreement which allowed for the use of a single room on the Church Street premises with the condition to sublet the remainder to Boyce, Leathern's tenant, in order to run a native eating House. Thus was initiated the provision of scant space to accommodate the requirements of the beer hall. Opened in May 1909, its primary role was to support

5. This was moved from its site on the Edendale Road to a position on what is now French Road. Pietermaritzburg Corporation Yearbook 1921 (Pietermaritzburg City Council, Pietermaritzburg, 1921), p 18.

6. Pietermaritzburg Archives Repository (hereafter NAB), Pietermaritzburg Corporation Files (hereafter PMB), 3 PMB 7/10/14, Minutes of the Police \&c Committee held on 20 April 1909. Item 330/09.

7. NAB: 3 PMB 7/10/18, Minutes of the Police \&c Committee, 27 July 1921.

8. Pietermaritzburg Corporation Yearbook 1918-1919 (Pietermaritzburg City Council, Pietermaritzburg, 1919), p 18.

9. Despite the financial imperative, in the Natal Almanac and Natal Directories these places are normally described as "eating houses" and little reference is made to the beer hall aspect.

10. A. Braby, Natal Directory 1920 (A.C. Braby, Durban, 1919).

11. It is important to note that this original beer hall space was located in close proximity to all the civic buildings of the city, as well as the city hall and Market Square. 
African people living and working in the centre of the city. ${ }^{12}$ It was soon found to be too small, and within two months attempts made by the corporation to extend the scope of the lease failed, leaving the beer hall in a cramped and unsatisfactory position, and for the corporation, a "standing difficulty". ${ }^{13}$

However, the temporary arrangements were just that; for a decade. On 6 August 1919, the chief native commissioner visited the different facilities in Pietermaritzburg, and comments were noted of the different establishments forming the beer industry in the city. The central beer hall in Commercial Road was found wanting; whilst it appeared clean, the facilities were very limited and the sanitation dire. The chief native commissioner recommended condemnation. ${ }^{14}$

Thus, by the end of the second decade of the twentieth century, the Pietermaritzburg corporation was compelled to terminate its arrangement with Leathern and thus negotiated for a different, but adjacent site. In September 1919, the city approached Mr J. Whitelaw with regard to purchasing a site on the corner of Pietermaritz and Commercial Roads, known at the time as "Whitelaw's Buildings" which was run as a wagon-making workshop. Whitelaw's property was purchased, and on 24 November of that year, the minutes of a meeting of the "Police \&c Committee" record that "the time had ... arrived when the matter of erecting suitable buildings for a Native Beer and eating house on the site purchased for that purpose in Pietermaritz Street was taken in hand....". Notice was given to the estate of W. Leathern to terminate the original lease. ${ }^{15}$

To achieve the required space, the wagon shop was stripped and transformed into a beer hall, on the Pietermaritz side, with an eating house at the rear. The space was sectioned into areas in which small butcheries could operate, goods sellers could store their goods, and parts of the veranda were let to hawkers. The eating house had an allocation of twenty tables which were let out to municipally sanctioned hawkers, or "squatters", who hired stalls from which they sold trinkets, snuff, and traditional medicaments required by the patrons of the beer hall in their quotidian operations. The corporation regarded this as being a "remarkably successful" system. ${ }^{16}$ The hawkers were usually Africans or Indians, and they had to apply for permission to trade. It is important to note that the building itself was still a retrofit arrangement, as opposed to a committed vision entailing the construction of a new, purpose designed building.

Paula du Plooy acknowledges these ancillary facilities as being vital components of an inner city society in the following paragraph:

The Corporation, therefore, at first concentrated solely on the production and sale of beer. Indeed, the Pietermaritzburg beer halls were initially just what their name implied; halls in which beer (utshwala) was sold. Within two years, however, the beer hall in Commercial Road had an eating house attached to it. Food was sold in the eating house by Africans themselves. This was the first step in the evolution of beer

12. NAB: 3 PMB 7/10/18, Minutes of the Police \&c Committee, 25 May 1909.

13. Pietermaritzburg Corporation Yearbook 1918-1919, p 18.

14. NAB: 3 PMB 7/10/14, Letter from Chief Native Commissioner, 6 August 1919.

15. NAB: 3 PMB 7/10/18, Minutes of the Police \&c Committee, 25 November 1919. It is not clear what "Police \&" refers to.

16. Pietermaritzburg Corporation Yearbook, 1924-1925 (Pietermaritzburg City Council, Pietermaritzburg, 1925), p 25. 
houses into social, recreational and entrepreneurial centres for Africans in the borough. ${ }^{17}$

Whilst she is quick to acknowledge the positive aspects, Du Plooy, also describes these spaces as cold, forbidding, hard and unyielding. ${ }^{18}$ Despite this physical environment, the social environment must have been quite different, given that the annual profits from beer sales due to the corporation from the central beer hall in particular, throughout most of the first part of the twentieth century tell of a vital and much used amenity for African people in the centre of Pietermaritzburg.

Factored into the consideration of spaces, as with many other aspects of Zulu culture, the beer halls were gendered, dictated in large part by the traditional roles of beer making (by women) and beer consumption (by men) thus creating strong ties between tasks and the spaces required to carry them out. While the beer was usually made off-site, the provision of food for the beer drinkers was a vital female role, as opposed to those areas dedicated to the consumption of beer. $^{19}$

They were also controversial spaces, for both urban Africans and other residents. Although they were intended from the outset to appeal to a broad sector of African society, the traditional practice of beer drinking did not meet with the approval of many African residents, particularly those schooled or belonging to missionary groups. Because of this, initially beer halls acted as vectors for fragmenting African society, setting aside "the better class of African" from the daily visitors. As will be expanded upon later in this article, the corporation realised this phenomenon, and tried to remedy the situation by offering a variety of different activities through the vehicle of the beer hall in an attempt to mollify those dissonant African residents. Despite this effort at broadcasting the appeal of the beer halls across different sectors of society to render them acceptable, protest did occur. Apart from the complaint of the conservative "temperance" sectors of society at the outset, given the prominence of largely Wesleyan amaKholwa in Edendale in particular, the years 1929 and 1960 heralded the celebrated beer hall protests which challenged the authorities. For a time, beer sales dropped and the profits accruing to the municipal native affairs authorities plummeted, but the success of the system was such that it prevailed beyond the protests. ${ }^{20}$

With the conversion of the wagon making shop on 11 April 1924, a more permanent central beer hall and associated eating house was opened on the corner of Pietermaritz Street and Commercial Road (currently occupied by the magistrate's court). Its position was an advantage, because by 1933 its profit margin exceeded the other beer halls in the city by some nearly $£ 1200$ in beer sales and nearly $£ 460$ in rents from tables let to "squatters". In fact, the fiscal acuity of the city with regard to beer sales was such that it was,

17. Du Plooy, "African Reaction to the Beerhalls", p 142.

18. Du Plooy. "African Reaction to the Beerhalls", p142.

19. Indeed, the gendered arrangement of the spaces and their management formed part of important historical critique with the gradual changes of roles of African women in the midtwentieth century.

20. While these events are important in the general story of the beer halls, in the context of this paper they are presented only as background to a greater social consciousness surrounding the system as a whole. 
... quite obvious from them [the profits] that the profit on the Pietermaritz Street Hall as a trading concern for the year 1933 was over $£ 1000: 00$ :0d and it should be remembered in this connection that the income for the year 1933 was considerably below what this Department regards as normal. The sales of Beer by the Department for one year should average somewhere about £8000:00:0d to $£ 9000: 00$ :0d: they have been as high as $£ 11000: 00: 0 d$...The profit from these sales, of course, goes into the Native Revenue Account and helps towards the cost of other activities undertaken by the Council through the Native Administration Department ... It will be realised that the great difference between the revenue from Pietermaritz Street and the other Beer Houses is mainly due to the central position of the Pietermaritz Street Beer hall, which enables Natives employed in stores, Government offices, domestic service and those attending Government offices and courts to spend a short time at this establishment obtaining foor (sic) or refreshment. If it is desired to endeavour to retain this revenue and provide easy facilities for the Natives it will be necessary to again establish a Beer Hall in a central position. ${ }^{21}$

The new central beer hall in Pietermaritz Street was a pivotal space for aggregation: although part of the documentation which was aimed at its retention in the centre of the city, the minutes of a meeting of the Beer Hall Committee, a group of concerned African citizens on 19 January 1934, noted that some 150 people had secured employment at the institution, as well as it being important for Africans from all walks of life, urban as well as rural, a place where they could have a meal and some drinks. The central proximity to the courthouse was indicated as being of vital importance. ${ }^{22}$

Over a quarter of a century, this beer hall had developed into a central locus for all things social - besides the aforementioned market stalls, it was also a space that hosted other functions for African patrons, particularly a weekly bioscope. In the early years of the 1930s, however, the Pietermaritzburg corporation offered this prime piece of inner city land to the government, on which to erect the new magistrate's court which still stands on this site today.

\section{Choosing the new site}

The central beer hall had to be relocated, and quickly. Instead of a cogent series of decisions being taken on a mutually appropriate site, the positioning of the beer hall was largely due to sites offered for sale to the city at the time, and from these, the best option chosen. No specific guidelines were given on an area where this should be positioned, given the variety of offers submitted.

The Pietermaritzburg corporation began casting around for potential sites from the beginning of 1934. A number of contenders were offered, many of which met with public disapproval. On 10 January 1934, Mr Thomas Cook, acting on behalf of Mr Berriman, offered the site on the corner of Pietermaritz and Commercial Roads for sale to the council. On 12 January 1934, A Thompson, offered the council the two erven numbered 45 and 46, situated between Berg and Boom Street. He noted in his letter that "The acquisition of these full erven would give the Corporation ample scope for the Beer House and the development of

21. NAB: 3 PMB 4/3/133 1299/1933.

22. NAB: 3 PMB $4 / 3 / 133$ 1299/1933. The author of the African voice in this deputation was not indicated. 
Sports Grounds". ${ }^{23}$ Three days later, R Stevens, manager of the municipal native administration department commented to the town clerk:

\begin{abstract}
Although these two pieces of land are very large and in themselves would suit the purpose for which they are offered, I am unable to recommend their purchase as I do not consider the sites as being in a suitable locality to which the Pietermaritzburg Beer Hall might be transferred. ${ }^{24}$
\end{abstract}

Stevens was aware that the site would be unsuitable for the beer hall customers because it was quite a distance from the centre of town. He was not in favour of its moving to this position, although, ironically, this was the site that was finally settled upon.

The challenge continued: another site offered was located on the corner of Retief and Longmarket Streets. This was motivated by Stevens as "a very large piece of land suitable for our requirements for a Native Beer Hall and market, and possibly a Bantu Social Centre". However, Stevens noted that from a business point of view, it was possibly placed a little too far out of the central part of town. In January 1934, a petition was submitted to the mayor, Cllr H. Collins, objecting against the relocation to Erf 17 Church Street - ideally central, but unsuitable in the eyes of many of the inner city residents. Some 368 people objected to this site, complaining of potential general rowdiness and that the "noise caused by the Natives will interfere with and disturb the worship of members of the congregation of St Peter's Cathedral and the Salvation Army Memorial Hall." Another option on the remainder of Lot 29 Church Street, a large erf which had street fronts onto Otto Street, Pietermaritz Street and Assurance Street also brought some negative reaction. It was recorded:

The property consists of nearly three quarters of an acre of land and has on it buildings of a most substantial and extensive nature, which with alteration, could be converted to house not only a beer hall, but probably a brewery as well as native recreation halls, including cinematograph hall etc. or the like. ${ }^{25}$

This last mentioned site found favour with a cohort of users of the beer hall and was strongly motivated in terms of location and size. Furthermore, it was a key area in the perhaps idealistic, though flawed public participation process.

In consultation with the potential African users of the site in February 1934, this Otto Street site as noted above was considered the best on the table. ${ }^{26}$ It was seriously considered until a petition with a mere 118 signatories was lodged, citing the potential for public nuisance, effectively scuppering the option. Most vocal was Robert Dunlop of the Pietermaritzburg Chamber of Commerce, who noted strongly: "This Chamber desires to enter its protest against any proposal to establish a Native Beer Hall in the centre of the business community." The largely white, inner city business community had voiced its objections.

None of the options, of which there were a few others, found favour, and Stevens was forced to revisit the offers submitted earlier. Although the Retief

23. The grounds were thinly occupied: some market gardens and some open ground, according to A. Braby, Natal Almanac and Directory for 1933 (A.C. Braby, Durban, 1933).

24. NAB: 3 PMB 4/3/133 1299/1933.

25. NAB: 3 PMB 4/3/133.

26. These buildings were also known as the "Old CID offices in Pietermaritz Street". 
Street site had been initially dismissed by him in January, by March it became real, given the lack of alternatives. On 14 March, the Natal Witness published a notice informing Pietermaritzburg citizens of the decision regarding the site for the new premises. However, this option also had its problems: rather than the powerful white businessmen in the centre of town driving the protest, this area was more demographically mixed, consisting of a melange of owners and tenants including Indian, coloured and white people, which made for interesting objections. ${ }^{27}$ They were strongly articulated, and more formally organised, coming from a variety of people from different race groups who were all resident close to the site, and all quoting safety and noise as factors. On 15 March 1934, one of these residents, a Mrs AM Foyles addressed a letter to the mayor and councillors of Pietermaritzburg, saying that even under current circumstances it was hardly safe enough to sit out on one's veranda at night, let alone with a beer hall in close proximity. Mr W Meares protested as strongly on the same date, noting that he had three properties adjoining Retief Street, that were all occupied by Europeans, and that he would battle to get tenants if the beer hall became a reality. ${ }^{28}$

Other races too, from different social and political groupings, had issues. The Natal Indian Congress requested a deputation to council which was supported by the Natal Coloured Welfare Association. On 18 March, a scheduled protest mass meeting was convened under the auspices of the Colonial Born and Settler's Indian Association (Maritzburg Branch) and local people were urged participate "to protest against the City Councillors' action in agreeing to the site in Retief Street, between Berg and Boom Streets for the establishment of a 'Native Beer Hall' ... Come in your hundreds and record your protest!" The contention was that the area under consideration was "mostly a residential area of Indians and Coloureds and that its location in this area would vastly increase incidents of crime, hooliganism and 'the dreaded amaeleitas"'. ${ }^{29}$ Furthermore, they were canny to point out that similar protests made by whites against the Otto Street site, amongst others in the centre of town, had been entertained based on the grounds of public nuisance, which was exactly their position too. On 19 March this petition from all parties was submitted with 403 signatures. On 20 March the Natal Witness reported on the meeting, noting the presence the convener committee headed by $\mathrm{Dr}$ Maurice $\mathrm{R}$ Peters; city councillors; Mr M.W. Walthew and Mr G. Benjamin representing the Natal and Maritzburg Coloured Welfare Society; and residents including Messrs Meares, Timm and Young "representing the European residents of Ward 8". The protest came to naught. By 21 March, the instruction to proceed with the purchase of the land had been put into action. The Colonial Born and Settlers Indian

27. The Natal Directory for 1932 mentions the generic terms "Indians" and "Coloureds" and then gives names such as Oosthuizen, Olckers and African Laundry which point to a polyglot environment. See A. Braby, Natal Directory 1932 (A.C. Braby, Durban, 1932), p 1032.

28. NAB: PMB 4/3142. Meares appears to have been a career protester, as there are numerous letters from him complaining about the potential of the beer hall, as well as the ramifications thereof. See NAB: 3 PMB 4/3/142, 305/934.

29. These were gangs consisting to some extent of male domestic workers. La Hausse, "The Struggle for the City", refers to them as being characterised by the "houseboy" in the ranks identified by the distinctive "uniform", p 32. The amaleitas continued to be cause for concern, as evidenced in the letter to the Editor of the Natal Witness by William Manyoni on 13 December 1934, complaining about the "maleita" menace at the "native" bioscope on Saturday evenings. 
Association appealed for an interview with the full council on 29 March 1934, to no avail. $^{30}$

Independent protest from African residents followed. However, much of their dissent was because they felt the location of the new beer hall was too distant from the centre of town rather than the affect on the residential area where it was to be erected. Guided by prominent leaders J.T. Gumede and Chief Sioka, ${ }^{31}$ an enigmatic result shows that the African opinion appears to have been mixed: on 10 April 1934, Stevens penned a letter to the town clerk to the effect that

the Petition dated 23 March, 1934, signed by four Natives, J.T. Gumede, Chief Sioka and two others, purporting to represent a large number of Natives' resulted in a significant result: 16 people voted against the Retief Street site, 10 voted in favour, and 29 people did not vote at all. ${ }^{32}$

The decision was taken. In an undated document, E.E. Russell noted that the chief native commissioner had inspected all the sites and opined:

... that as a matter of ploicy (sic) the wise course is to maintain one large central Beer Hall ... i.e. one reasonably easy of access for natives ... and to group round it as far as may be other activities in the interest of natives ... that of the sites offering the most suitable for this purpose is the plot known as "Matthews" land, corner of Retief and Berg Streets.

These two properties were largely unoccupied, one lot being vacant, and the other occupied by "Indian gardens" for a number of years. ${ }^{33}$

It took just under four months to design the building and produce the tender documentation; tenders for its construction were offered on 14 July 1934. Messrs Booth and Clark were initially awarded the tender on 28 July 1934 for an amount of $£ 9350$, to build the beer hall and market. They had, however, erred in their calculations and withdrew their tender, which thus reverted to the next submission which was for an amount of $£ 9745$. As with all municipal monies, this extra amount was a budgetary issue. Harry Lugg, then the chief native commissioner protested this error, forcing the town clerk to make further application for the outstanding funds, eventually allowing for the appointment of Messrs Robert Barras to construct the building. The fast-track construction began at the end of July 1934, and the imperative was such that variation orders within the contract arose a number of times and were similarly objected to by an evidently embarrassed Lugg. In October, he remonstrated:

...The procedure adopted by you of submitting a series of ever-increasing estimates for the same service has already necessitated the Minister being approached on two

30. NAB: 3 PMB 4/3/133 1299/1933.

31. J.T. Gumede was part of the 1919 visit to England by the South African National Native Convention in an attempt to repeal the Native Land Act of 1913, and became president of the African National Congress in 1927. Chief Sioka, together with Gumede and Stephen Mini formed part of the representation to the Native Economic Commission in 1931. See J. Holloway, Report of the Native Economic Commission 1930-1932 (Government Printer, Pretoria, 1932). Sioka (Siyoka) and Mini were chiefs of the amaKholwa in Edendale as explained in N. van Warmelo, A Preliminary Survey of the Bantu Tribes of South Africa (Government Printer, Pretoria, 1935), p 31.

32. NAB: 3 PMB 4/3/133 1299/1933, Letter to the Town Clerk, from Stevens, 10 April 1934.

33. A. Braby, Natal Directory 1932, p 1032. 
occasions ... apparently, it will be necessary to obtain his approval a third and fourth time before your requirements can be satisfied.

The town clerk replied:

The peculiar circumstances surrounding the erection of the Beer Hall in Retief Street is to a certain extent responsible for the amended figures. The Council having entered into an agreement with the Government to hand over the site of the present Beer Hall for the erection thereon of the new Law Courts, it became necessary for the erection of a new Beer Hall to be immediately proceeded with.

In any event, by 7 December the complex had been completed, two weeks ahead of schedule. The plans production, tender process and construction period for a major element of municipal infrastructure had taken some eight months. Unlike the other temporary buildings, this was constructed as a flagship building for the city infrastructure, while its predecessor in Pietermaritz Street was demolished, and the roofing iron and timber from the old building was stored in the municipal stables for reuse.

Similarly fast tracked was its opening. The new model Berg Street Hall was opened with great fanfare on Tuesday 11 December 1934 at $11 \mathrm{am}$. The invitation list included luminaries such as the mayor of Durban and the administrator of Natal, but also the mayor of Pietermaritzburg and the chief native commissioner, Harry G Lugg. ${ }^{34}$ Stevens requested that some 120 gallons of beer be available for free distribution, and suggested that on the night of the second day, a "Native concert and dance be given to the better class Natives who have, in the past, hired the beer hall for concert purposes and who in the future I hope will make more use of the facilities offered". This was the beginning of the social life of the new beer hall, and the formation of a flagship space for the city.

\section{The beer hall and associated identity}

A number of authors including Du Plooy and La Hausse firmly take the position that the municipal beer halls, to which people went voluntarily, were places of oppression. ${ }^{35}$ However, as already noted, beer sales in most years could support the argument that perhaps at the same time they were vital institutions in the inner city for marginalised groups in a dispensation where there were few other options. While from the lofty position of a retrospective view beer halls were hard and unfriendly places, these other indicators show that they also had social value. Furthermore, this credence is highlighted in the continued contemporary life, albeit infamous, of the Berg Street Beer Hall

Even though beer halls and their associated eating houses were controlled by the city authorities, they achieved a specific identity over the years. Paul la Hausse records, from an interview with S.B. Borquin, that the beer halls in Durban were known as "eMatsheni", or the "place of stones". This name was derived from the time prior to the introduction of the legislated monopoly of beer sales by the municipality, when women would sit on large stones outside the Durban station to

34. Natal Witness, 12 December 1934, p 9.

35. Paula du Plooy, for example, records their liminal position between acceptance and rejection. See Du Plooy, "African Reaction to the Beerhalls", p 142; and the works by La Hausse indicated in footnote 1. 
sell their beer. ${ }^{36}$ In Pietermaritzburg, the new beer hall was similarly named eMatsheni, while others appeared to retain nomenclatures related to their location. Berg Street Hall was referred to as the New Matsheni Hall suggesting that this was a name tied to the central institution as an abstract idea rather than being site specific. Indeed, it is still referred to as Matsheni Beer Hall today.

This specific construction of a generic name is one which is tied intimately to the perception of specific spaces for closely defined functions as identified by the African users of the institutions. Despite Paula du Plooy's description of these as being cold and forbidding spaces, an element of their existence indubitably became tied to a sense of identity and belonging.

The city spent much effort convincing the African patrons that this was a space that belonged to them, while at the same time wielding what they considered was necessary control. As noted above, the evening after the opening at which some 120 gallons of beer was freely available, the city organised a gala event, a concert and dance for invited guests, some 500 in all, including a sit-down dinner. They fitted a stage so that public events could take place. ${ }^{37}$ It was also used as demonstration space: local "cook boys" were instructed by city officials on the use of electricity for cooking. On 31 July 1937 the first weekly "talkie bioscope" was shown at the beer hall, and in the same annual report it was recorded that the stage had been enlarged and footlights installed. ${ }^{38}$ In addition, in May of that year, the coronation of Queen Elizabeth II was celebrated, and among other gestures such as providing free beer at the various beer halls, the city organised 188 free meals to "deserving" Africans and provided an eleven-valve wireless set so that the patrons of the beer hall could listen to the coronation at Westminster Abbey. On 6 March 1939, beer was supplied to women for the first time in a separate room from their men folk. In the same month, the corporation commenced the opening of the venue on Sundays, finding that this was beneficial in keeping people from drifting off to drink in what they called the "black belts" around the city. ${ }^{39}$

As far as extending the social ambit of the beer hall was concerned, the city was careful to set boundaries, enticing the better-heeled client. Ezra Caluza applied to hire the hall for at least 16 nights per month, a lease agreement to which the corporation acceded for a period of two months, because they had noted that the concert events they organised were generally poorly attended. ${ }^{40}$ The condition was, as far as dancing was concerned, that none of the traditional "native" dances such as ngoma or ndhlamu which involved stamping, were allowed but ballroom dancing was. It appears that even Caluza battled to get attendance on these events, because at the end of the following month in September, he cancelled his contract, suggesting that the cold weather may have

36. La Hausse, "The Struggle for the City", p 47.

37. Pietermaritzburg Corporation Yearbook, 1936-1937 (Pietermaritzburg City Council, Pietermaritzburg, 1937), p 109.

38. Pietermaritzburg Corporation Yearbook, 1937-1938 (Pietermaritzburg City Council, Pietermaritzburg, 1938), p 133.

39. Pietermaritzburg Corporation Yearbook, 1939-1940 (Pietermaritzburg City Council, Pietermaritzburg, 1940), p 142. This had been disallowed by Harry Lugg, the Chief Native Commissioner at the time of its opening. See Natal Witness, 12 December, $p 9$.

40. NAB: 3 PMB 4/3/170 339/1935, Charges for hire of hall at Berg Street Native Hall and market. Letter Stevens to Town Clerk, 26 September 1935. 
had an impact on attendance. ${ }^{41}$ Itinerant parties were hosted by the African Social Party Club, Pietermaritzburg, hosted by F.W. Moffatt as conducting manager, J.T. Gumede as president, J. Olifant as stage manager, P. Sioka as chairman, Radebe as conductor and D. Mdluli as secretary. The gentlemen promised: "Singing, dancing, speeches, joy to meet every chest", together with "supper, smokes, all refresments (sic) and fruit". ${ }^{42}$ Interestingly, the Edendale elite, active actors in the social critique of the beer hall, continued as ardent supporters in such events.

And so, after its establishment at the end of 1934, the Berg Street Beer Hall became an integral part of a local African culture at the lower end of the city, albeit largely under city control. As had been the case with the earlier building, traders and hawkers had to apply for sites for trading, and the city saw fit to regulate this. Obed Mkhize met with the full weight of the city when he tried to open a barber's shop in the complex, and was bluntly informed that the maximum number of such businesses allowed was two. He also campaigned for his friend Simon Mlaba, a "native chemist" who was similarly disadvantaged. ${ }^{43}$ The hawkers' stalls were a valuable form of income for the city, as evidenced by spreadsheets in its annual accounts from year to year, yet at the same time, the city exerted control over their allocation.

The focus of the Berg Street Beer Hall and its influences extended further than the boundaries of the site. Soon after trade began, the plot of open land known as Lot 45 opposite the beer hall which was included in the original purchase in 1934 became a point of contention. A letter from R.R. Gopaul to the town clerk in July 1935 complained of it being used as a thoroughfare by drunken people and that the city should fence it. ${ }^{44}$ This followed on earlier correspondence of November 1934 in which the secretary of the Maritzburg and District Lawn Tennis Association (Native), a Mr Kunene, appealed for courts for tennis, citing that it was a suitable game for "women and domestic servants" to play, because it was the chief sport in the native training colleges. ${ }^{45}$ Indeed, Kunene stressed that location of such facilities close to the beer hall and eating house in Berg Street appeared logical, rather than the distant Fitzsimmons location. In 1937 the corporation began to consider this earlier application, largely because provision of such facilities which would also act as a buffer zone between the beer hall and the suburb. ${ }^{46}$ On 8 September 1937 negotiations on terms of usage were opened with the Maritzburg and District Lawn Tennis Association (Native) and by 4 April 1938, the courts had been constructed. Interestingly, the parties who submitted tenders for their construction were B. Maharaj, R.M. Moodley \& Son and E.P. Naicker, demonstrating an active engagement for tenders between the city and a rising

41. NAB: 3 PMB 4/3/170 339/1935, Charges for hire of hall at Berg Street Native Hall and market. Letter Stevens to Town Clerk, 26 September 1935.

42. NAB: 3 PMB 3 PMB 4/3/170 339/1935, Ticket to social party, New eMatsheni Hall.

43. NAB: 3 PMB 4/3/170 339/1935, Letter Obed Mkhize to Town Clerk, 22 January 1935.

44. NAB: 3 PMB 4/3/254 139/1938. Native Lawn Tennis Association, Application for construction of tennis court on land opposite new native beer hall. Letter R. Gopaul to Town Clerk, 15 July 1935. Gopaul noted that he had European tenants in his property which adjoined, and that they were complaining.

45. NAB: 3 PMB 4/3/254 139/1938, Native Lawn Tennis Association, Application for construction of tennis court on land opposite new native beer hall. Letter Kunene to Municipal Native Administration Department, 29 March 1938.

46. NAB: 3 PMB 4/3/254 139/1938, Native Lawn Tennis Association, Application for construction of tennis court on land opposite new native beer hall. Letter R. Stevens to Town Clerk, 3 September 1937. 
Indian middle class of entrepreneurs. However, the council decided that they could construct the grounds departmentally at an amount much less than the lowest tendered price by Maharaj at £95. On 4 April 1968 it was resolved that an amount of $£ 60$ be budgeted for the construction. ${ }^{47}$ On 15 November 1938 the Maritzburg and District Lawn Tennis Association (Native) took over the site, paying a rental of $£ 1$ per month. ${ }^{48}$

In terms of beer sales, earlier records note years of bad revenue, attributed to the 1918 influenza, the 1929 beer riots, and general recessions from time to time. Beer sales rose during the Second World War. The Pietermaritzburg Corporation Yearbook for 1941-1942 records that the wartime years were prosperous for the beer hall, since it was well patronised by African soldiers stationed in the city. ${ }^{49}$ Furthermore, after the old brewery was scrapped and the new one on the corner of Orhtmann and Fitzsimmons Roads was erected, beer quality improved and beer sales rose commensurately. ${ }^{50}$

While this paper thus far has blended the social elements of the history together with the practical process of site choice and construction, little has been said about the buildings themselves. These formed part of a virtually invisible network of apartheid era, beer related activity around the city, yet comprised a vital part of the social functioning of the city itself, catering to a fundamentally important sector of society, the workforce.

For many people in present-day Pietermaritzburg, these buildings remain physically and socially invisible. The Berg Street Beer Hall as well as the single men's hostel for black workers are both substantial buildings, yet are located behind walled enclosures. The "new" brewery in Orhtmann Road, constructed in the early 1950s stands alone, without identifying markers and lost from the memory of people who have lived in the city their whole lives. As elements of municipal material culture they are invaluable, speaking of social lives and past political dispensations, while at the same time they are substantial buildings that were solidly constructed, allowing for potential re-use in creative and innovative ways.

\section{The beer hall as structure}

Most of the research for this article was undertaken by exploring archival material, and various editions of the Pietermaritzburg corporation's yearbooks. Sadly, the once useful plans repositories of the city have been misplaced, and little institutional memory on the planning and construction of these buildings remains. Plans for the new Berg Street Beer Hall (1934) have not been located in the archives as yet, although similar plans for the recreation hall in Sobantu drawn up in the same year point perhaps to the same designer in the employ of the city. The plan of the Sobantu hall, sadly is not authored. The façade of the new Central Fire Station (1935) too, has the characteristic stepped feature of the Berg Street beer

\footnotetext{
47. NAB: 3 PMB 4/3/254 139/1938. Committee minute, 4 April 1938.

48. Today this site is occupied by the Retief Street taxi rank.

49. Pietermaritzburg Corporation Yearbook, 1941 - 1942 (Pietermaritzburg City Council, Pietermaritzburg, 1942), p 23.

50. Du Plooy, "African Reaction to the Beerhalls", p 142.
} 
hall, suggesting that the design of civic architecture of the time was consistent and displayed the same rigorous attention to detail.

The municipal architecture in Pietermaritzburg in the 1930s is located subsequent to a dominant late Edwardian / Union period style of the 1920s, which employed flat Roman bricks, roughcast plaster, hipped Marseilles tiled roofs and teak fenestration (windows) and doors. The 1930s heralded a simplified, pared down version of its predecessor, employing to some degree, the same architectural toolkit, after which the late 1940s brought in an experimental modernism which lasted until the 1960s, employing vertical concrete fins, daringly thin flat slab roofs, and somewhat whimsical asymmetrical façade treatments.

While it would be tempting to suggest that this robust and simplified architecture of the mid-1930s employed in the Berg Street Beer Hall was the result of the considerations of its intended user group as well as the end use of the building itself, parallels with similar municipal structures from the same time are a valuable comparison, showing that there was a general trend in architecture across the municipality, rather than buildings being treated in specific ways. Electrical substations for instance, point to an increasing simplicity after the departure of H.E. White, an electrical draughtsman, from the electricity department in the early 1930s. He was a slave to pattern architecture, combining all the elements required in Union period architecture into a specific Pietermaritzburg style. His successor did not employ the same sense of nostalgic style in his buildings, meaning that the substations of the 1930s were generally simple, well made, but utilitarian structures. Furthermore, the elaborate and considered modernist principles embodied in the early 1950s structures for the municipal native administration department, such as the Orhtmann Road brewery and the new high rise blocks at the East Street "native" hostels for men, point to an implementation of good and innovative architecture across the city regardless of who the end users were.

By the mid-twentieth century, the city architects had begun to develop an architecture that responded to the perceived needs of the end users. It had broken away from the nostalgic whimsy of the Victorian era and developed a solid, urban interface with a simple architectural language of reasonably monolithic proportions. While this architectural language may be interpreted on the one hand as one which was hard and impregnable, intentionally keeping the unwanted elements "in" and shielded from view, at the same time it also created a deliberately viable and to some extent, personal public space that the inhabitants could own and defend, prioritising the requirements of the beer hall users. It is also important that these seemingly modest and simply detailed structures have a design rigour which although couched in early modernism, sets them apart from the poorly designed municipal infrastructure of today.

The main entrance to the beer hall complex is from Berg Street (now known as Hoosen Haffajee Road) after which the building is named. This façade is almost Egyptian in its symmetrical monolithic treatment. It has a subtly stepped central entrance which is detailed in red face-brick, with more systematically stepped flanking walls treated with plaster and inset with large steel windows to each side. What were paired palm trees to each side of the entrance completes the symmetry, reinforcing an architectural consideration of the façade. The yard to the 
left is walled with large gates set in stoic gateposts, resulting in solid structure creating a firmly defined corner; this adds to an architecture of enclosure and at the same time, one of exclusion. Compared with the dense, overcrowded facilities which were vacated at the end of 1934, the balance of inside and outside space, considered market facilities, as well as the provision of a clearly defined, deliberately designed and owned space, rather than a retrofit afterthought, the new Berg Street beer hall presents a confident stamp of commitment to the African people by the city of Pietermaritzburg, as well as confirmation that the Durban System was a viable vehicle for the provision of municipal infrastructure in the city. ${ }^{51}$

The Retief Street façade is a solid wall of buildings of domestic proportions, with hipped corrugated iron roofs concealing a courtyard. The inside edge of the wall contains a number of shops, which would have been let in the past. The courtyard too contains separate shops. Within this courtyard the beer hall is located with a side entrance, and also the kitchen, characterised by a flotilla of chimneys, which provided huge open fireplaces for cooking food. The Retief Street entrance is secondary, indicated only by a break in the monolithic wall indicating an entrance, thus forcing the main focus of the building to Berg Street after which the building is named.

Sadly, the robust and serviceable architecture of the 1930s was "modernised" in the 1980s, detracting from the more elegant older architecture by adding a clumsy layer onto the building to its southern elevation, as well as the main entrance from Berg Street.

Today, the Berg Street Beer Hall operates with a different impetus: the massive kitchen is closed and boarded up, and the spaces in which the officially sanctioned hawkers used to trade have been taken over by new informally appointed users. It is no longer subject to the strictly administered municipal control that characterised its past, and while remaining a vital place of contact for many, has achieved a level of notoriety due to the lack of official management of its spaces. Today it is known rather for informal beer brewing and sales, and drug peddling, and thus also for regular police raids. Furthermore, a number of informal buildings have been erected in the yard. The city has had little interest in the complex for many years, further marginalising the marginalised that currently use it. While in the past the city was careful in its perhaps paternalistic management, it was those controls that kept the "amaleitas" at bay, and maintained stability for the patrons; indeed the protection of the people in the beer hall was priority. It is ironic that given removal of municipal control, modern day "amaleitas" have taken control.

In conclusion, this paper has described the expedited development of the Berg Street Beer Hall. In itself a controversial space, the initial dismissal of the site by the authorities as being too big was subsequently revised. Despite the other sites in the centre of town receiving fewer protests by residents, those objections by people of mixed race groups together with a few white landowners of the lower end of town fell on deaf ears. Importantly, there existed a social discourse on its

51. At the same time, it is probably the decision to move the beer hall to the lower end of Berg Street that to large extent informed the manner in which the city later implemented the Group Areas Act from a spatial perspective. 
construction - perhaps enabled by a more enlightened social system in the 1930s. Furthermore, over the years a variety of different approaches were explored in order to make this space viable and acceptable to its clientele. In addition, a political imperative was largely the generator for the speedy construction of the building so that the site for the new law courts could be handed over to the government. More importantly, despite the fact that this space is still well used, there has been no management or maintenance by the city in the last two decades. It is now a filthy, almost desolate architecture which contains animated functions. It is protected: it is well over the 60 year clause as prescribed by the KwaZulu-Natal Provincial Heritage Act, but unlike the men's hostel in East Street which can be reconfigured into inner city high density housing, the municipal beer hall has specifically ordered spaces which require creative reworking in order to make the building useful and meaningful. While any approaches to the city and the ward councillor have thus far fallen on deaf ears, perhaps a close scrutiny of the development plans, together with active public participation, can suggest a meaningful rather than "top down" approach towards re-conceptualising what in the past appears to have been an energetic space.

\begin{abstract}
Southern African cities have quietly developed by plugging new civic infrastructure that supported their operations into the urban environment, often with ad hoc decisions eliciting public outcry. Occasionally, legislative imperatives led to active protest, particularly the implementation of early versions of Group Area legislation. In the early twentieth century, the Pietermaritzburg corporation was torn between the need to accommodate Africans within the city for labour purposes and simultaneously, the need to follow legislations which restricted exactly this. Accommodating labour was the key component of the Durban System allowing for the control of African beer consumption while providing vital municipal revenue. The requisite buildings thus formed a vital part of city infrastructure. The original central beer hall was located close to the city hall and other important centres of civic society. It was marked for closure in the early 1930s, and reconstructed in a part of the city populated largely by mixed race and Indian people who protested vociferously at its development. This article discusses the public consultation process and the formation of the beer hall as a core of African-centred development on the periphery of the city. It concludes by commenting on the structures in contemporary Pietermaritzburg and their potential for future, meaningful development.
\end{abstract}

Keywords: beer halls; municipal buildings; Durban System; Pietermaritzburg.

\title{
Opsomming
}

Suid-Afrikaanse stede het gaandeweg ontwikkel deur die toevoeging van nuwe stedelike infrastrukture wat hul werksaamhede in die stads-omgewing ondersteun het dikwels deur ad hoc besluitneming met gevolglike publieke reaksie. Wetgewende opdragte het nou en dan gely tot daadwerklike protes aksie in besonder die implementering van vroêre weergawes van die Wet op Groeps Gebiede. Die Pietermaritzburg munisipale bestuurders was verdeeld in die vroeë jare van die twintigste eeu oor die noodsaakliheid om voorsiening te maak vir akkommodasie van swart arbeid in die stad en tegelykertyd die toepassing van 
wetgewing wat dit beperk het. Om die werkers te akkommodeer, was die sleutel element van die Durban-sisteem terwyl die geoorloofde verbruik van Afrika-bier voorsiening gemaak het vir noodsaakliheid munisipale inkomste. Die betrokke geboue vorm dus ' $n$ belangrike aspek van die stedelike infrastruktuur. Die oorspronlike sentraal biersaal was naby die stadsaal en ander belangrike munisipale en burgerlike sentrums. In die vroeë dertiger jare was dit geoormerk vir sluiting en vir herontwikkeling in ' $n$ gedeelte van die stad waar gemeenskappe, meestal van gemengde en Indier oorsprong woonagtig was, hewig protes aangeteken het teen die ontwikkeking daarvan. Hierdie artikel bespreek bogenoemde gebeure, die deelname van die publieke protes aksie en die ontwikkeling van die biersaal op die buiterand van die stad as die kern van Afrikagesentreerde ontwikkeling. Ter afsluitung sal die artikel komentaar lewer op huidige strukture in Pietermaritzburg en die potentiaal daarvan op toekomstige sinvolle ontwikkeling.

Sleutelwoorde: biersale; munisipale geboue; Durban-sisteem; Pietermaritzburg. 